To cite this article: Bolu E. Akintunde, Yacob Haliso \& Zachariah Obinna Okoro (2021) Leadership Style, Business Information Use and Corporate Social Responsibility Practice in Credit Direct Limited Lagos State, Nigeria. Information Impact: Journal of Information and Knowledge Management, 12:1, 1-13, DOI https://dx.doi.org/10.4314/iijikm.v12i1.1

To link to this article: https://dx.doi.org/10.4314/iijikm.v12i1.1

\title{
Leadership Style, Business Information Use and Corporate Social Responsibility Practice in Credit Direct Limited Lagos State, Nigeria
}

\author{
${ }^{1}$ Bolu E. Akintunde \\ ${ }^{1}$ Yacob Haliso \\ ${ }^{1}$ Zachariah Obinna Okoro \\ ${ }^{1}$ Department of Information Resources Management, Babcock University Ogun State, Nigeria
}

\begin{abstract}
A survey research design was used for this study. The population comprised Two hundred and fifty-six (256) staff of Credit Direct Limited, Lagos State. Total enumeration was used. A self-designed structured questionnaire was used to collect the data. Cronbach's alpha reliability coefficient was used to test the reliability of the research instrument. Data analysis was done using descriptive statistics. The findings revealed that both leadership style and business information use have positive influence on corporate social responsibility practice in Credit Direct Limited, Lagos State $\left(\mathrm{R}^{2}=\mathbf{H}_{3}: \mathrm{R}=.253 ; \mathrm{R}^{2}=.064 ;\right.$ Adjusted- $\mathrm{R}^{2}=.056 ; \mathrm{F}(2,8.631) ;$ Sig. $=0.000$ ). the level of corporate social responsibility practice is high, for leadership style, transformational leadership was highly used and finally business information was highly used. The study concluded that corporate social responsibility practice in the organization will be enhanced if there is a significant improvement in her leadership style and business information use. The study recommended that the management of credit direct limited, Lagos state should improve their level of corporate social responsibility through adequate utilization of business information available to them, the leadership style that encourages CSR practice should be adopted and they should also improve on their corporate philanthropy which will enhance the image of the organization.
\end{abstract}

\section{Keywords}

Business Information, Corporate Social Responsibility, Transactional Leadership, Transformational

CONTACT Bolu E. Akintunde, Yacob Haliso and Zachariah Obinna Okoro ukangwaclement@gmail.com Obafemi Department of Information Resources Management Babcock University Ilishan-Remo,Ogun State, Nigeria 2021 The Authors Published with License by Information Impact

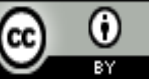




\section{Introduction}

Credit Direct Limited (CDL) is a non-bank finance company operating as a subsidiary of First City Monument Bank (FCMB), CDL provides soft loan to its customers. CDL contributes to the development of its society through the following corporate social responsibility practice, for example some of its social responsibility practices; upgrading schools and providing adequate learning tools for students, provision of free health checks for the customers, professional trainings of customers on entrepreneurial skills and services. Credit Direct Limited prioritizes the welfare of its stakeholders. The concept of corporate social responsibility (CSR) is viewed as the responsibility of an organization towards its stakeholders with the intentions of improving their standard of living. According to Sridhar (2015) corporate social responsibility is viewed as the ethical behavior that an organization exhibits towards its internal and external stakeholders as well as the responsibility of the organization towards the environment and society in which it operates. Azim (2011) established that financial institutions face the challenge of practicing corporate social responsibility as well as commitment to sustainable development. Therefore, credit direct limited is not immune to this challenge. Corporate social responsibility is regarded as the lifeblood of the organization, it is about the organization and its management being able to recognize their responsibilities towards its stakeholders. Hence, organizations that engage in corporate social responsibility are perceived to behave ethically and morally attached to the internal and external environment of its operation. The practice of corporate social responsibility as a means of improving the well-being of a community can be demonstrated when there is a focus on the needs of the community, for example through the provision of boreholes, electricity transformers, security patrol vehicles, ethical business practice, policy development that favours the society and including charity giving.

Charitable giving is an aspect of corporate social responsibility that implies philanthropic responsibility. Business organizations fulfill their philanthropic responsibility by donating their time, money, or resources to charities at national or international levels. Ethical business practice is coined from the term ethics, which is a standard of morality within which organizations uphold the beliefs accepted by the society. According to Jamali and Mirshak (2007) corporate social responsibility practice is about focusing on philanthropic responsibilities. In the context of practicing ethics in business, stakeholder expects the organization to be fair and honest in the discharge of their duties which is usually in terms of fairness and moral beliefs. Policies are principles adopted by an organization to guide the decisions and business practice within the organization. Organizations develop policies that will meet social, political, and economic needs of the community. According to Bonituo, (2014) the survival and sustenance of corporate social responsibility depend greatly on a company's development strategy and on the company's ability to identify, promote and implement successful policies and practices aimed at 
satisfying all stakeholders' concern. Economic responsibility suggests decisions that are made by considering their overall effect on society and the organization. Economic responsibility as a practice of corporate social responsibility focuses on striking a balance between business, environmental and philanthropic practices.

According to Keskes (2014) leadership style as the relationship between an individual and a group based on common interests and they behave according to the directions of the leader. Leadership is viewed as the process of influencing people to direct their efforts towards achieving organizational goals. The style of leadership plays a role towards the performance and efficiency of an organization. According to Leparleen, (2014) successful leadership style inspires enthusiasm and commitment. Therefore, without leadership, organizations move too slowly, stagnate, and lose their way which results to poor performance, absence of motivation, poor growth, and development of the institution (Ukaidi, 2016).

Transformational leadership is a leadership style that encourages followers, enhances employee motivation and beliefs in the goals of the organization. They are perceived as organizational transformer; this is because they change ideas and communicate new ideas to followers in a clear and motivating way. Business information is very crucial to corporate social responsibility practice in the organization. The success or failure of any business process relies on the quality of information that is being utilized, which in the business perspective is otherwise known as business information. Gallway (2002) describes the quality of information as one that is relevant, credible, topical, balanced, and accessible. Furthermore, for organization to use business information, it must come from good source. The source of business information are competitors, customers, business associates, government officials, broadcast media, libraries, newspapers/periodicals/magazines, government publications, trade and industry associations, and electronic sources.

The purpose of using business information is to improve business processes. Business information is needed not just to improve the processes and performance, but also the feasibility in the long run. Business Information is an important factor to any organization in the sense that businesses use information gathered to support the day-to-day operations, decision making and in all the functional areas in a business and it has a vital role to play within an organization. Information is a critical resource in any given economy (Okoro, Haliso \& Otuza, 2019). For usability of business information, the type of information that is needed must be considered, whether the information will be suitable for the task it will be used for or managers will have to compromise in terms of their needs. Business Information use is important to organization because it helps them to know the kind of product that is taken into the marketplace thereby helping the business maximize profit, achieving a large customer base and also avoiding any future occurrence in political change that may affect the business processes. 
The practices of corporate social responsibility have a very important role of influencing the productivity of employees, enhancing the corporate image of the organization as well as improving profitability. However, despite this emphasis, the study will be focusing on the commitment to the CSR practice of organizations, to ascertain whether most business organizations with respect to those in the financial sector are truly committed to the practices corporate social responsibility. Therefore, it becomes a matter of empirical investigation to determine the cause of this anomaly if it is because of the leadership style of the organization or a lack in the use of business information. Studies have established a direct relationship between the style of leadership and the use of business information with the conduct of business operations. This implies that without the integration of a good leadership style and the use of business information, the practice of corporate social responsibility may not be achieved. Therefore, it was in the interest of the researchers to investigate the influence of leadership style and business information use on corporate social responsibility practice in Credit Direct Limited, Lagos state.

\section{Objective of the Study}

The main objective of this study was to investigate the influence of leadership style and business information use on corporate social responsibility practice in Credit Direct Limited, Lagos State. While the specific objectives of this study were to:

1. find out the level of corporate social responsibility practices in Credit Direct limited, Lagos state.

2. examine the leadership style practiced by Credit Direct Limited, Lagos State.

3. determine the level of Business Information Use by Credit Direct Limited, Lagos State.

4. examine the influence of leadership style on corporate social responsibility practice in Credit Direct Limited, Lagos State.

\section{Research Hypothesis}

To achieve the stated objectives, the following hypothesis stated in null form was tested at 0.05 level of significance

1. Leadership style will not significantly influence corporate social responsibility practice in credit direct limited, Lagos state

2. Business information use will not significantly influence corporate social responsibility practice in credit direct limited, Lagos state

3. Leadership style and Business information use will not jointly influence corporate social responsibility practice in credit direct limited, Lagos state 


\section{Literature Review}

According to Yusuf (2009) Corporate Social Responsibility (CSR) is a form of self-regulation, conscious attempts and self-efforts undertaken by organizations for self-preservation and enhancement of their operations. CSR is partly a result of the fact that social problems differ from society to society, and this in turn tend to define the role that business must play in each society as well as the expectations of society on how and to what extent business should help in solving social problems. McWilliams and Siegel (2011) regard corporate social responsibility as a firm's responsibility to enhance social interest. This responsibility goes beyond laws and the firm's interest. Mohr and Webb (2001) further point out that CSR is the commitment made by a company to remove or reduce its adverse impacts on the society, and meanwhile boost the long-term beneficial influences on the society. Matten and Moon (2008) define CSR as policies and actions adopted by a corporation to reflect its responsibilities to advance social interests.

The success or failure of any business process relies on the quality of information that is being utilized called Business information. Gallway (2002) has described the quality of information as one that is relevant (meets the criteria of the question and be useful); credible (the source is well-known); topical (up-to-date or a hot topic); balanced (represents an important and perhaps, under-represented point of view); and accessible (easily available and written in a clear way) (Haliso \& Alao, 2013). Business information is a managers' fundamental resource (Hannula \& Pirttimäki(2005).

Sunil (2018) noted that, Leadership style is a key determinant towards the success or failure of the organization and is the behavioral approach of the leader to provide motivation and direction to his people. Leadership style is distinct based on the leader's attributes and it varies from totally strict and rigid behavior to quite flexible and participative behavior (Ojokuku, Odetayo,\& Sajuyigbe, 2012). As posited by Shurbagi and Zahari (2012) every leader has their own attitude, behavior, and style, which are a result of the organization's individual internal culture and create a style of management which prevails and represents a standard of conduct for leaders who are expected to adopt. The style of leadership that is operative within an organization should be the one that is effective and will be in accordance with the vision statement of the organization.

Fuente, (2017) seem to stress the importance of transformational leadership above transactional leadership as it relates to environmental responsibility, stating in conclusion that "transformational leaders are needed to effect transformations in the way humankind relates to the natural environment. Business information is very crucial to corporate social responsibility practice in the organization. Business information is a managers' fundamental resource which is useful for doing business. Haliso and Okunfulure (2010) Quality business information use enables an organizations CSR practice to be sustainable and competitive. BIU enables an organization to develop propositions for a strategic CSR 
practice. Business information use provides knowledge to CSR leaders on ways to efficiently utilize CSR information for the benefit of the organization.

Recent enthusiasm about the topic of responsible leadership highlights certain deficiencies in current leadership theories, particularly about the interface between leadership and CSR (Shyam, 2016). Vishwakarma, (2019) investigated corporate social responsibility and found positive correlation between business information on corporate social responsibility. The study further stated that leadership and business information is an integral part of every organization and remains viable for the sustenance and existence of the organization. Khoa and Phuong (2020) noted that managers of business should have access to a wide range of accurate and competitive business information and, also, should be conversant with the dynamics to discover these information sources. CSR practices have also become a component of business organization that enhances competitive advantage and long-term sustainability. Ohaka, and Ogaluzor, (2018) findings reveal a positive relationship between business information and corporate social responsibility practice. They further stated that adequate business information helps an organization to achieve competitive edge over its competitors. The generated business information is also vital for other organizational activities such as advertising, remuneration and forecasting.

\section{Methodology}

The study adopted survey design. The sample comprised all the 256 employees of credit direct limited, Lagos state. As a result of the small size of the population, total enumeration was adopted. The research instrument used for the data collection is a self-designed questionnaire. Data was collected using questionnaire. The questionnaire used was structured. The Data collected were analyzed using the Statistical Package for Social Sciences (SPSS Version 21). Descriptive statistics such as simple percentage value (\%), mean, standard deviation, Frequency counts were used. Also, linear and multiple regressions was used to test the hypotheses to examine the effects of the independent variable on the dependent variable

\section{Presentation of Results}

Table 1: Demographic characteristics of the respondents

\begin{tabular}{|c|c|c|}
\hline Gender & Frequency & Percentage \% \\
\hline Male & 112 & 43.8 \\
\hline Female & 144 & 56.3 \\
\hline Years of working experience & Frequency & Percentage \% \\
\hline less than a year & 26 & 10.2 \\
\hline $1-2$ years & 33 & 12.9 \\
\hline 5-7 years & 40 & 15.6 \\
\hline 8-10 years & 79 & 30.9 \\
\hline 10 years and above & 78 & 30.5 \\
\hline
\end{tabular}




\begin{tabular}{|c|c|c|}
\hline Age & Frequency & Percentage \% \\
\hline less than $18-24 y r s$ & 37 & 14.5 \\
\hline $25-35 \mathrm{yrs}$. & 53 & 20.7 \\
\hline $36-45$ yrs & 93 & 36.3 \\
\hline 46yrs and above & 73 & 28.5 \\
\hline Highest Academic qualification & Frequency & Percentage \% \\
\hline BSc & 164 & 64.1 \\
\hline MSc & 92 & 35.9 \\
\hline
\end{tabular}

\section{Source: Field Survey, 2021}

Results reveal that $43.8 \%$ of the respondents are men while $56.3 \%$ are women. $36.3 \%$ of the respondents were between 36 - 45 years old, $28.5 \%$ of the respondents were between 46 years old and above, $20.7 \%$ of the respondents were between 25 - 35 years old, and the remaining 14.5 were mostly 18 - 24 years old. Research Objective 1: To find out the level of corporate social responsibility practices in Credit Direct limited, Lagos state.

This study indicated corporate social responsibility practice has been subcategorized into ethical responsibility, Charitable Giving, policy development and economic responsibility. The results show that the respondents agree that: their organizations engage in ethical responsibility with the Mean $=2.91$, their organization engage in charitable giving with mean Mean $=3.42$, their organization engage in policy development with Mean $=2.95$, and economic responsibility with Mean $=3.08$. Generally, the result shows that the respondents agree that there is an engagement of corporate social responsibility practices in credit direct Limited, Lagos state.

Research Objective 2: To examine the leadership style practiced by Credit Direct Limited, Lagos State.

The study indicated, leadership has been subcategorized into transactional leadership style and transformational leadership style. The results show that the respondents agree that transactional leadership style is being practiced in their organization with the Mean $=3.28$. The result equally shows that transformational leadership style is being practiced by Credit Direct Limited, Lagos State with the Mean $=3.46$. Generally, the result shows that the respondents agree that both transactional and transformational leadership style are practiced in credit direct Limited, Lagos state with the Mean = 3.37.

Research Objective 3: determine the level of Business Information Use by Credit Direct Limited, Lagos State.

For this study, business information use has been subcategorized into sources of business information, purpose of use and extent of use. The results show that the respondents agree that Government Bodies, Virtual: via search engines, CBN Financial Reviews, Chamber of Commerce, Media, Peer Groups, Universities, Professional Services are all source of business information in their organization with the 
Mean $=3.02$. The result equally shows that is useful to Credit Direct Limited, Lagos State with the Mean $=3.11$. Furthermore, the findings reveal that the respondents agree that the usefulness of business information is to a large extent. Generally, the result shows that the respondents agree that Business Information Use is high in Credit Direct Limited, Lagos State with the Mean = 3.17.

Hypotheses: The three (3) hypotheses were tested at a significant level of 0.05.

Hypothesis one: Leadership style will not significantly influence corporate social responsibility practice in credit direct limited, Lagos state.

Table 2: Regression analysis of the Leadership style on corporate social responsibility practice in credit direct limited, Lagos state

\begin{tabular}{|c|c|c|c|c|c|c|}
\hline \multirow[t]{2}{*}{ Model } & & $\begin{array}{l}\text { Unstandardized } \\
\text { Coefficients }\end{array}$ & & $\begin{array}{l}\text { Standardized } \\
\text { Coefficients }\end{array}$ & $\mathrm{t}$ & Sig. \\
\hline & & B & $\begin{array}{l}\text { Std. } \\
\text { Error }\end{array}$ & Beta & & \\
\hline \multirow[t]{2}{*}{1} & (Constant) & 30.443 & 2.703 & & 11.264 & .000 \\
\hline & $\begin{array}{l}\text { LEADERSHIP } \\
\text { STYLE }\end{array}$ & .163 & .066 & .153 & 2.462 & .014 \\
\hline $\begin{array}{llr}\text { a. } & \text { Dependent } & \text { Variable: } \\
& \text { CORPORATE } & \text { SOCIAL } \\
& \text { RESPONSIBILITY PRACTICE } \\
\mathrm{R}= & \text {.153; } \mathrm{R}^{2}=.023 ; \text { Adjusted- } \mathrm{R}^{2}= \\
.019 ; & \mathrm{F}(1,6.062) ; \text { Sig. }=0.000\end{array}$ & & & & & & \\
\hline
\end{tabular}

The result reveals that the independent variable has a positive coefficient, which is an indication that leadership style positively influences corporate social responsibility practice in credit direct limited, Lagos state $\left(\mathrm{R}=.153 ; \mathrm{R}^{2}=.023\right.$; Adjusted $-\mathrm{R}^{2}=.019 ; \mathrm{F}(1,6.062)$; Sig. = 0.000). The result also shows an $\mathrm{R}$ value of 0.153 which reveals that there is $15.3 \%$ weak positive correlation between leadership style and corporate social responsibility. The $\mathrm{R}^{2}$ of 0.023 reveals that the independent variable (leadership style) accounts for $2 \%$ of the variations in the performance of employees. The results further disclose that while holding the influence of leadership style constant, the corporate social responsibility is recorded to be positive $(\beta>0)$. However, the coefficient of leadership style $(\beta=.163)$, indicates that an improvement (i.e., $1 \%$ increase) in the leadership style of leaders in credit direct limited, Lagos state, will lead to an improvement (i.e., $16.3 \%$ increase) in the practice of corporate social responsibility in the establishment. The F statistics of 6.062 which is significant at $p<0.05$, further gives us an empirical evidence that leadership style has a statistically significant influence on corporate social responsibility. Hence, the null 
hypothesis which states that Leadership style will not significantly influence corporate social responsibility practice in credit direct limited, Lagos state is rejected.

Hypothesis two: Business information use will not significantly influence corporate social responsibility practice in credit direct limited, Lagos state.

Table 3: Regression analysis of the Business information corporate social responsibility practice in credit direct limited, Lagos state

\begin{tabular}{|c|c|c|c|c|c|c|}
\hline Model & & $\begin{array}{l}\text { Unstandardized } \\
\text { Coefficients }\end{array}$ & & $\begin{array}{l}\text { Standardized } \\
\text { Coefficients }\end{array}$ & $\mathrm{t}$ & Sig. \\
\hline & & $B$ & $\begin{array}{l}\text { Std. } \\
\text { Error }\end{array}$ & Beta & & \\
\hline 1 & (Constant) & 30.467 & 2.047 & & 14.885 & .000 \\
\hline & $\begin{array}{l}\text { BUSINESS } \\
\text { INFORMATION USE }\end{array}$ & .142 & .044 & 200 & 3.248 & .001 \\
\hline 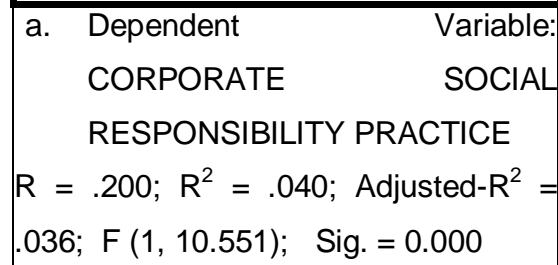 & & & & & & \\
\hline
\end{tabular}

The result reveals that the independent variable has a positive coefficient, which is an indication that business information use positively influences corporate social responsibility practice in credit direct limited, Lagos state $\left(\mathrm{R}=.200 ; \mathrm{R}^{2}=.040 ;\right.$ Adjusted- $\mathrm{R}^{2}=.036 ; \mathrm{F}(1,10.551) ;$ Sig. $\left.=0.000\right)$. The result also shows an $\mathrm{R}$ value of 0.200 which reveals that there is $20.0 \%$ weak positive correlation between business information and corporate social responsibility. The $\mathrm{R}^{2}$ of 0.040 discloses that the independent variable (business information) accounts for $4 \%$ of the variations in the performance of employees. Furthermore, the results disclose that while holding the influence of business information constant, the corporate social responsibility is recorded to be positive $(\beta>0)$. However, the coefficient of business information $(\beta=$ .142), shows that an improvement (i.e., 1\% increase) in the business information of credit direct limited, Lagos state, will bring about an improvement (i.e., 14.2\% increase) in the practice of corporate social responsibility in the organization. The $\mathrm{F}$ statistics of 10.551 which is significant at $p<0.05$, further gave us empirical evidence that business information has a statistically significant influence on corporate social responsibility. Hence, the null hypothesis which states that business information use will not significantly influence corporate social responsibility practice in credit direct limited, Lagos state is hereby rejected. 
Hypothesis three: Leadership style and Business information use will not jointly influence corporate social responsibility practice in credit direct limited, Lagos state.

Table 4: Regression analysis of the combined influences of leadership style and Business information use will not jointly influence corporate social responsibility practice in credit direct limited, Lagos state

\begin{tabular}{|c|c|c|c|c|c|c|}
\hline Model & & \begin{tabular}{|l} 
Unstandardized \\
Coefficients
\end{tabular} & & $\begin{array}{l}\text { Standardized } \\
\text { Coefficients }\end{array}$ & t & Sig. \\
\hline & & B & $\begin{array}{l}\text { Std. } \\
\text { Error }\end{array}$ & Beta & & \\
\hline 1 & (Constant) & 23.686 & 3.346 & & 7.080 & .000 \\
\hline & LEADERSHIP STYLE & .166 & .065 & .155 & 2.546 & .011 \\
\hline & $\begin{array}{l}\text { BUSINESS } \\
\text { INFORMATION USE }\end{array}$ & .143 & .043 & .201 & 3.311 & .001 \\
\hline $\begin{array}{llr}\text { a. } & \text { Dependent } & \text { Variable: CORPORATE } \\
& \text { SOCIAL } & \text { RESPONSIBILITY } \\
& \text { PRACTICE } \\
\mathrm{R}= & .253 ; \mathrm{R}^{2}=.064 ; \text { Adjusted- } \mathrm{R}^{2}=.056 ; \mathrm{F}(2, \\
8.631) ; & \text { Sig. }=0.000\end{array}$ & & & & & & \\
\hline
\end{tabular}

To determine the combined influences of leadership style and business information on the corporate social responsibility practice in credit direct limited, Lagos state, results shows that the independent variables (leadership style and business information) have positive coefficient, which shows that they have positive influence/relationship on/with corporate social responsibility. $\left(\mathrm{R}=.253 ; \mathrm{R}^{2}=.064\right.$; Adjusted- $\mathrm{R}^{2}=.056 ; \mathrm{F}(2,8.631)$; Sig. $\left.=0.000\right)$ The result further shows an $\mathrm{R}^{2}$ value of 0.253 which shows that the independent variables account for $25.3 \%$ of the variations in the corporate social responsibility practice in credit direct limited, Lagos state The results also show an F-statistics of 8.631, which is a measure of the aggregate effect of the independent variables on the dependent, and with a pvalue $<0.05$ ( $p=0.000)$, it is evident that the combined influence of the independent variables (leadership style and business information) on the corporate social responsibility practice in credit direct limited, Lagos state, is statistically significant. Hence, the null hypothesis that states that Leadership style and Business information use will not jointly influence corporate social responsibility practice in credit direct limited, Lagos state is hereby accepted.

\section{Conclusion}

The study has revealed the leadership styles, business information use, and the CSR practices of Credit Direct Limited. The study revealed that leadership style significantly influences corporate social responsibility practice in Credit Direct Limited, Lagos State. Therefore, corporate social responsibility practice in the organization will be enhanced if there is significant improvement in her 
leadership style. The study also revealed that business information use significantly influences corporate social responsibility practice in Credit Direct Limited. The study has revealed that the organization seeks information from various sources and uses this information in meeting their CSR. Furthermore, the results from the findings of the study indicated that business information use and leadership style positively influence corporate social responsibility practice of Credit Direct Limited.

\section{Recommendations}

Based on the findings of the study, the following recommendations were made:

1. As indicated in the study charitable giving is the most engaged corporate social responsibility practice, therefore, the management of Credit Direct Limited, Lagos State should improve on their corporate social responsibility practice through increasing their charity giving, policy development, economic responsibility, and ethical responsibility.

2. The findings indicated that leadership style is vital to the success of corporate social responsibility practices in Credit Direct Limited Lagos State Nigeria. Hence, as the study revealed transformational leadership style is most used, this leadership styles encourages the CSR practice and should continue to be used.

3. It is also recommended that the organisation keeps up its business information use as the respondents agreed with the usefulness of business information use.

\section{References}

Areiqat, A., Abdelhadi, T., Abu Rumman, A., \& Al-Bazaiah, S. (2019). The effect of corporate social responsibility in achieving competitive advantage at jordanian supply chain. International Journal of Supply Chain Management, 8(2), 531-540.

Azim M., Ahmed E. \& Netto D. B. (2011). Corporate social disclosure in Bangladesh: A study of the financial sector. International Review of Business Research Papers, 7(2).

Bonituo, P. I. (2014). Assessing the Benefits and Challenges of Corporate Social Responsibility in the Kumasi Metropolis: A Case of The Beverage Industry. A Thesis submitted to the Department of Managerial Science, Kwame Nkrumah University of Science and Technology in partial fulfilment of the requirements for the degree of Master of Business Administration.

Colvin, R.E. (2002). Transformational leadership: A prescription for contemporary organizations.

Fuente, J. A. (2017). The role of the board of directors in the adoption of GRI guidelines for the disclosure of CSR information. Journal of Cleaner Production, 141, 737-750.

Gallway, M. (2002). Quality control in information services for development. Information Development, $18(3)$.

Haliso, Y. \& Alao, O. A. (2013). Information use and decision making by market women in Lagos Nigeria. Journal of Information and Knowledge Management, 3. 
Haliso, Y. \& Okunfulure, O. (2010). Information sources utilization and job performance of workers in MTN Ibadan, Nigeria. International Research Journal in Information Resources and Knowledge Management, 1(1), 42-53.

Hannula, M. \& Pirttimäki, V. (2005). A cube of business information. Journal of Competitive Intelligence and Management, 3, 34-40.

Jamali, D., \& Mirshak, R. (2007). Corporate social responsibility: Theory and practice in a developing country context. Journal of Business Ethics, 72, 243-262.

Keskes, I. (2014). Relationship between leadership styles and dimensions of employee organizational commitment Intangible Capital IC, 10(1): 26-51.

Khoa, T. T. \& Phuong, V. N. (2020). Corporate social responsibility: gindings from the Vietnamese paint industry. International journal article, 12(3) 1-20.

Leparleen, C. S. (2014). Leadership Styles and Performance of Commercial Banks in Kenya. A Research Project Submitted in Partial Fulfillment of the Requirements of Degree of the Master of Business Administration, School of Business, university of Nairobi.

Matten, D. \& Moon, J. (2008). "Implicit" and "Explicit" CSR: a Conceptual framework for a comparactive understanding of corporate social responsibility. Academy of Management Review, $33(2)$.

McWilliams, A. \& Siegel, D. (2011). Corporate social responsibility: A theory of the firm perspective. Academy of Management Review. 26(1).

Mohr, L. A, Webb, D. J, \& Harris, K. E. (2001). Do consumers expect companies to be socially responsible? The impact of corporate social responsibility on buying behavior. Journal of Consumer Affairs. 35(1).

Ohaka, J. \& Ogaluzor, O.I. (2018). Corporate social responsibility accounting and the effect of donations on profitability of oil and gas companies in Nigeria. International journal of academic research in accounting, 8(3) 265-276.

O’Hare, C. (2007). Business information sources: a beginner's guide. Facet publishing 7(3)

Ojokuku, R. M., Odetayo, T.A. \& Sajuyigbe, A.S. (2012). Impact of leadership style on organizational performance: A case study of Nigerian banks. American journal of business and management, 1(4): 202-207.

Okoro, O. J., Yacob, H., \& Otuza, E. C. (2019). Influence of Business Information Use on Performance of Small and Medium Enterprises in Port-Harcourt Nigeria. Library Philosophy and Practice (eJournal). Retrieve October 16, 2020 from https://digitalcommons.unl.edu/libphilprac/2215 
Shurbagi, A. M. \& Zahari, I. B. (2012). The Relationship between Organizational Culture and Job Satisfaction in National Oil Corporation of Libya. International Journal of Humanities and Applied sciences, 1(3), 88-93.

Shyam, R. (2016). An analysis of corporate social responsibility in India. International journal of research, 4(5).

Sridhar, K. (2015). A Study on Corporate Social Responsibility Initiatives of Wipro Ltd. Research Gate.

Sunil, K. R. (2018). Literature Review on Leadership, Leadership Theories, Style and Leadership Development. International Journal of Research in Business Management. 6(6), 13-24.

Ukaidi, C. U. (2016). The Influence of Leadership Styles on Organizational Performance in Nigeria. Global Journal of Human Resource Management, 4(4), 25-34.

Vishwakarma, V. (2019). Corporate social responsibility: A literature review. International journal of management. $7(1)$

Waldman, D.A. (2018) Leadership and outcomes of performance appraisal processes', Journal of Occupational Psychology 60, 177-186.

Yusuf, F.A. (2009). Corporate social responsibility in Nigeria. International bar association. Retrieved from www.ibanet.org. 